\title{
Two new Upper Oligocene Gastropods from the North Sea Basin
}

\author{
KAI INGEMANN SCHNETLER
}

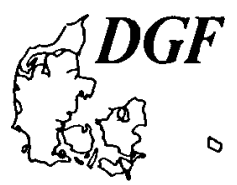

\begin{abstract}
Schnetler, K. I.: Two new Upper Oligocene Gastropods from the North Sea Basin. Bull. geol. Soc. Denmark, vol. 34, pp. 199-204, Copenhagen, December, 19th, 1985. https://doi.org/10.37570/bgsd-1985-34-15

Cerithiopsis (Cerithiopsis) jutensis and Coptochetus (s.lat.) danicus are established from the Upper Oligo-cene deposits of the North Sea Basin. The genus Cerithiopsis is represented in this Basin by several spe-cies, while the genus Coptochetus has not previously been recorded. Affinities of the two new species are discussed.
\end{abstract}

K. I. Schnetler, Fuglebakken 14, Stevnstrup, DK-8870 Langå, Denmark, January 21st, 1985.

\section{Introduction}

Since the studies by Harder (1913) and Eriksen (1937) no treatment of the danish Upper Oligocene molluscs has been made. New collections of material from several new localities have given a great material, which has considerably enlarged the number of Upper Oligocene species known from Denmark. The new material includes the two new species, described in this work. It is the intention of the present autor later to give this material, together with material from older collections, a thorougly treatment, but primarily descriptions of the two new species are given.

\section{Localities (fig. 1)}

Near the village Nr. Vissing is a small claypit, currently used by Galten Brickworks. The claypit has been described by Friis \& Nielsen (1978: 27). The fauna consists of about 85 species of molluscs.

At Skanderborg a big glacial floe of Upper Oligocene glauconitic clay was found in 1976 by the construction of the highway. An extensive amount of material was collected by Søren Bo Andersen, Geologisk Institut, Århus. The fauna consists of about 120 species of molluscs and is thus the richest known molluscan fauna from Upper Oligocene deposits in Denmark.

On the southern coast of the Trelde peninsula a very limited outcrop of Upper Oligocene glauconitic clay is located in a small coastal cliff at
Kirstinebjerg Skov. The clay overlies Søvind marl, and the fauna is very similar to the fauna from Skanderborg. About 100 species of molluscs have been found.

Systematic descriptions

Class: Gastropoda Cuvier, 1797

Order: Mesogastropoda Thiele, 1929

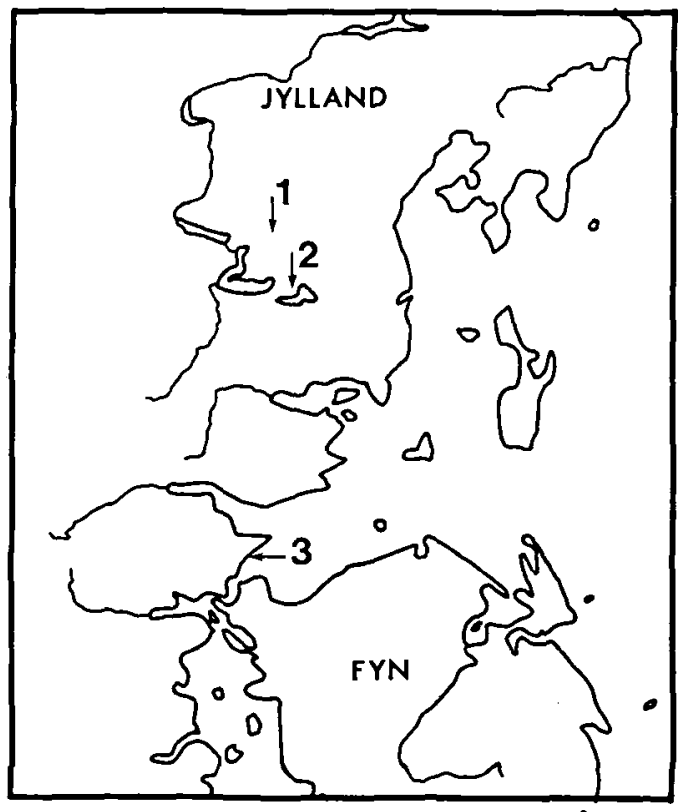

Fig. 1. Map showing localities (Jutland). 1: Nr. Vissing, 2: Skanderborg, 3: Kirstinebjerg Skov. 


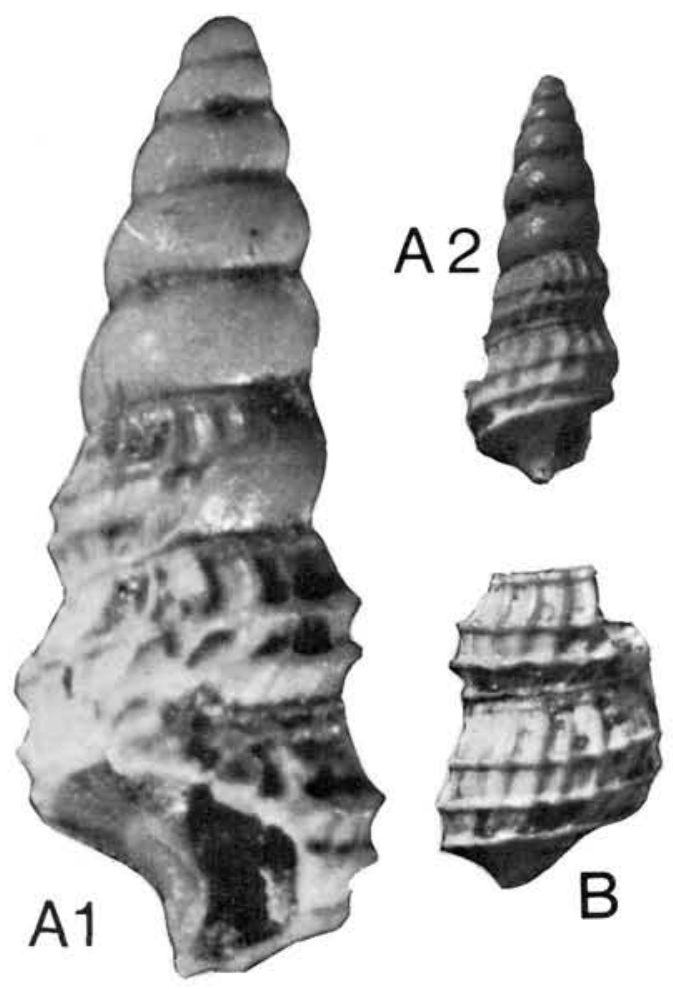

Fig. 2. Cerithiopsis (Cerithiopsis) jutensis n.sp.

Al: Lateral view of the holotype, MGUH $16808 \times 60$, showing transition from the protoconch to the teleoconch. - A2: Apertural view of the holotype, x24. - B: Sculpture of a younger whorl, probably of the holotype. Paratype, MGUH $16809 \times 24$.

Family: Cerithiopsidae H. \& A. Adams, 1854

Genus: Cerithiopsis Forbes \& Hanley, 1849

Cerithiopsis (Cerithiopsis) s.str.

Cerithiopsis (Cerithiopsis) jutensis n.sp.

Fig. 2

Holotype: MGUH 16808

Paratype: MGUH 16809

Locus typicus: Highway excavation near Skanderborg

Stratum typicum: Upper Oligocene glauconitic clay

Derivatio nominis: jutensis, Latin $=$ Jutlandish

Diagnosis: A Cerithiopsis s.str. with about 22 opisthocline collabral ribs. On the base there is a spiral rib at the transition to the canal. Spiral sculpture consisting of 3 spiral ribs, of which the adapical one is weaker than the others.

Material: Skanderborg 1 specimen, consisting of protoconch and 2 medium whorls. A fragment of a younger part of the teleoconch ( $1 \frac{1}{2}$ whorls) probably belongs to the same specimen. Kirstinebjerg Skov 1 specimen, consisting of 3 whorls of the protoconch and 2 medium whorls.

Description: The shell is small, highly turriculate, and slender. The protoconch is multispiral, comprising 5 convex, smooth whorls, separated by deep sutures. The nucleus is small. On the last half whorl of the protoconch fine, opisthocline growth lines are seen, being of the same shape as the aperture of the protoconch, which is sharp and opisthocline. Furthermore a slight depression on the middle of the world is seen. This depression continues on the teleoconch as the space between the two strong spiral ribs.

Of the teleoconch only 2 medium whorls and a fragment of the younger part of the shell are present. The 3 spiral ribs suddenly appear: Adapically a weak spiral rib, close to the suture, is seen. This spiral rib is much weaker than the two other spiral ribs, and on the two present specimens it never reaches their strength. Of the two strong spiral ribs the adapical one is placed a little above the middle of the whorl, while the abapical spiral rib is placed about one third of the whorl above the abapical suture. The space between the adapical, weak spiral rib and the adapical strong spiral rib is much greater than the space between the two strong spiral ribs.

The teleoconch is provided with a collabral sculpture, consisting of about 22 opisthocline ribs, which are weaker than the two strong spiral ribs. On the present material the number of collabral ribs seems to be rather constant. The collabral ribs are much weaker than the space between them. At the intersection between collabral ribs and spiral ribs oval granules appear, most prominently on the two strong spiral ribs. Fine growth lines are visible between the collabral ribs.

The flat base is demarked adapically by a fourth rather strong, smooth spiral rib. At the transition to the siphonal canal a rather weak spiral rib is visible. The aperture is rounded rectangular. The columella is concave and a little twisted. The siphonal canal is broken off, but clearly turned to the left side.

Measurements (protoconch and 2 medium whorls of the holotype): Length of the axis 1.6 $\mathrm{mm}$, maximum diameter $0.7 \mathrm{~mm}$. 

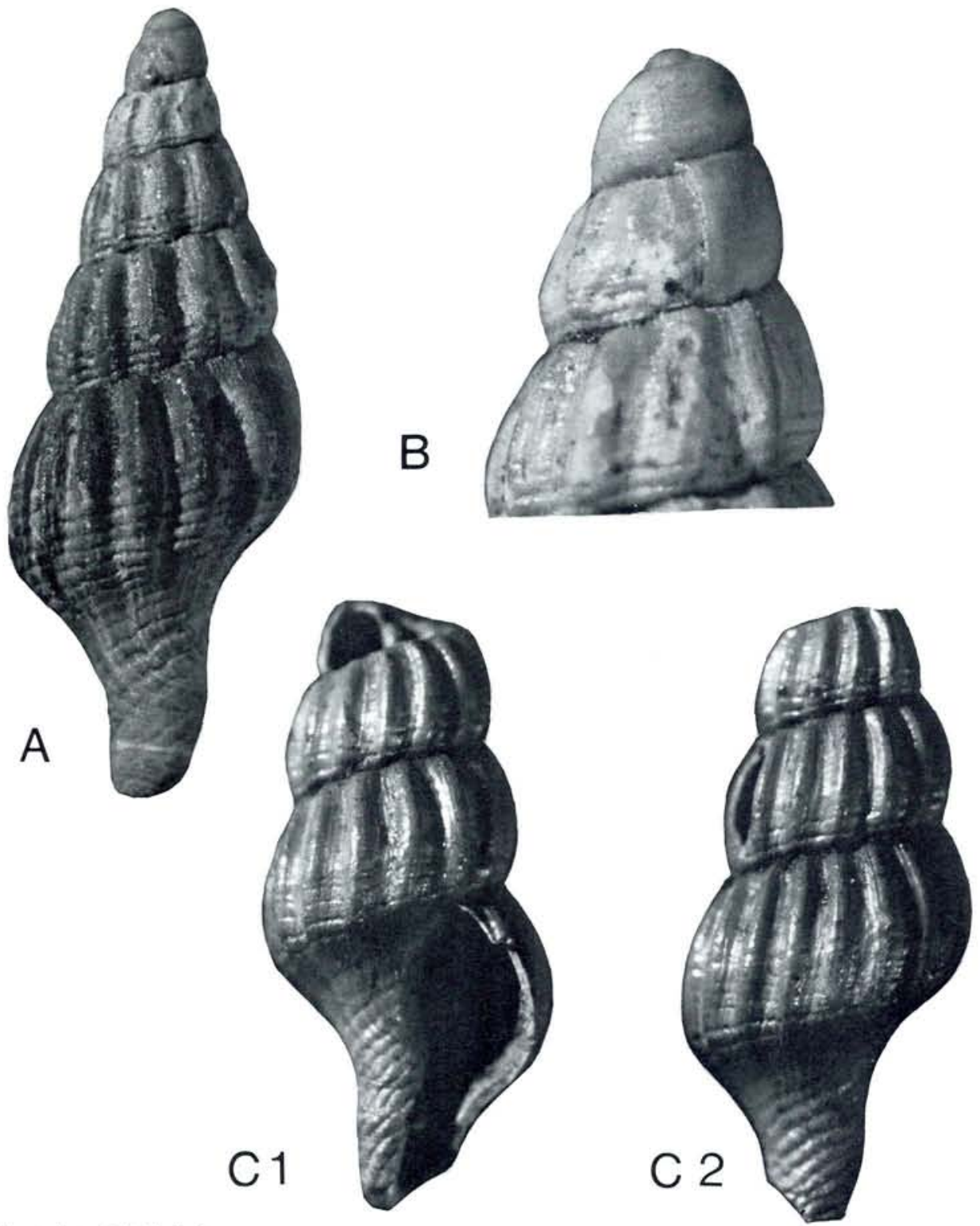

Fig. 3. Coptochetus (s.lat.) danicus n.sp.

A: Rear view of the holotype, MGUH 16810 x18. Locality; Nr. Vissing. - B: Protoconch of paratype, MGUH 16811 x43. Locality: Skanderborg. - C1: Apertual view of paratype, MGUH 16812. x18. Locality: Kirstinebjerg Skov. - C2: Rear view of MGUH 16812 $\mathrm{x} 18$.

Discussion: In agreement with R. Janssen (1978) and A. W. Janssen (1967) I refer the present species to Cerithiopsis s.str. because of the multispiral, smooth protoconch. R. Janssen (1978) recorded a great number of Upper Oligocene species of the genus Cerithiopsis. The following species have a quite different protoconch (and consequently cannot be referred to Cerithiopsis s.str.): C. (s.lat.) aff.dautzenbergi Glibert, 1949; C. (s.lat) bimonilifera (Sandberger, 1859); $C$. (s.lat.) serrula R. Janssen, 1978; C. (s.lat.) gradata R. Janssen, 1978; C. (s. lat.) daphnelloides R. Janssen, 1978; C. (s.lat.) ariejansseni R. Janssen, 1978 .

C. (C.) henckeliusii (Nyst, 1836) has a multispiral, smooth protoconch, but the spiral sculp- 
ture consists of 3 almost equal ribs placed equidistantly.

C. jutensis differs from $C$. soellingensis by a greater number of collabral ribs, a spiral rib on the base at the transition to the canal, the collabral ribs are more opisthocline, the transition between protoconch and teleoconch is opisthocline, and finally the shell has a more slender form and a sharper sculpture.

A. W. Janssen (1967) recorded a great number of Miocene species of the genus Cerithiopsis from Dingden, Western Germany. The following species have a different protoconch: $C$. (s.lat.) dautzenbergi Glibert, 1949; C. (s.lat.) sp. and ?C. (s. lat.) asperulata (Cossmann \& Peyrot, 1921).

C. (C.) vogeli $\mathrm{A}$. W. Janssen, 1967 differs from $C$. jutensis by the transition from the protoconch to the teleoconch is sigmoidal, the spiral sculpture consists of 3 equidistant spiral ribs, and finally the axial sculpture consists of $13-15$ prosocline axial ribs.

C. (C.) andersoni A. W. Janssen, 1967 differs from $C$. jutensis by the transition from the protoconch to the teleoconch is sigmoidal, the spiral sculpture consists of 3 equidistant spiral ribs and the number of axial ribs is $\mathbf{1 2 - 1 5}$.

Mr. A. W. Janssen, Rijksmuseum van Geologie en Mineralogie, Leiden made a direct comparison of the specimen from Skanderborg with the type material of $C$. vandermarki in Museum of Natural History in Rotterdam. According to the statement of Mr. A. W. Janssen (pers. comm. 1982) C. jutensis differs from $C$. vandermarki by the aperture of the protoconch is opisthocline, the two upper spiral ribs have a greater space, the whorls are considerably more convex, and finally the collabral ribs are considerably more opisthocline. A. W. Janssen refers $C$. vignali from the Arnum formation of Denmark, described and pictured by Sorgenfrei (1958: 170, pl. 31, fig. $105 \mathrm{a}-\mathrm{b})$ to C. vandermarki.

Cerithium genei Michelotti, 1849, described and pictured by Ravn (1907: 97, pl. 6, fig. 23) probably belongs to the genus Cerithiella.

Order: Neogastropoda Wenz, 1938

Family: Buccinidae Latreille, 1825

Genus: Coptochetus Cossmann, 1889

Type species: Fusus scalaroides Lamarck, 1803

Coptochetus (s.lat.) daniscus n.sp.

Fig. 3
Holotype: MGUH 16810

Paratypes: MGUH 16811-16812

Locus typicus: Claypit near Nr. Vissing

Stratum typicum: Upper Oligocene glauconitic clay

Derivatio nominis: danicus, Latin $=$ Danish

Diagnosis: A Coptochetus with a spiral sculpture of broad spiral bands, which are strongest abapically. The collabral sculpture consists of strong, almost orthocline ribs. On the first medium whorl 11 ribs are seen, increasing to $15-16$ on the last whorl.

Material: Nr. Vissing 1 specimen (holotype), Skanderborg 3 specimens, and Kirstinebjerg Skov 1 specimen.

Description: The shell is small, fusiform, and slender. The protoconch is paucispiral, consisting of $2-2 \frac{1}{4}$ convex whorls, of which the first $3 / 4$ is smooth and glossy. The small nucleus is depressed and a little obliquely placed. The following $1 \frac{1 / 4}{4}$ whorls are provided with about 13 weak spiral bands, separated by very fine spiral grooves. Adapically, these spiral bands and grooves are extremely fine, while they abapically are stronger. The transition to the teleoconch is sharp, consisting of an almost orthocline rib, which forms the aperture of the protoconch.

The teleoconch consists of about 2 medium whorls and the last whorl. The whorls are slightly to medium convex and are separated by deep sutures, which are undulate because of the placing of the collabral ribs. The whorls are about twice as broad as their height. The spiral sculpture consists of weak, broad spiral bands, which are separated by narrow spiral grooves. On the adapical part of the whorl these spiral bands and grooves are almost invisible, while they abapically are very prominent. On the first medium whorl 3 abapical spiral bands are seen, on the second medium whorl are 4 , and on the last whorl 5 spiral bands. The number of spiral bands thus increases by one for each whorl. The abapical spiral bands and grooves pass uninterruptedly and undulating over the collabral ribs, while they adapically are almost invisible on the collabral ribs.

The cóllabral sculpture consists of 11-16 strong, almost orthocline ribs, separated by a space of almost the same width. The ribs are placed almost regularly below each other on the 
whorls. On the first medium whorl 11 collabral ribs are seen, and on the holotype the number increases to 15 on the last whorl. The specimen from Kirstinebjerg Skov has 16 collabral ribs on the last whorl; these ribs are more opisthocline and close-set. On the teleoconch fine, slightly opisthocyrt growth lines are seen.

The base is convex. The spiral bands on the adapical part of the base are very weak, but they become stronger on the neck of the canal, where they are very distinct. About 8 broad spiral bands are seen here, passing irregularly across the growth lines. On the specimen from Kirstinebjerg Skov the spiral bands are almost invisible on the base. The collabral ribs disappear by the transition to the base. Only growth lines are present.

Labrum is broken off on all specimens, but the specimen from Kirstinebjerg Skov allows a description of the aperture, which is oval and rather wide. The canal is of almost the same length as the aperture and slightly turned to the right. The growth lines show that labrum is almost orthocline. Columella is smooth, slightly concave adapically, abapically passing into the canal. The inner lip is not very distinctly demarked.

Measurements of the holotype: Length of the axis $5.4 \mathrm{~mm}$, maximum diameter $2.0 \mathrm{~mm}$, last whorl $3.6 \mathrm{~mm}$, and aperture plus canal $2.4 \mathrm{~mm}$.

Variations: The specimens from Nr. Vissing and Skanderborg agree very well in all features, while the specimen from Kirstinebjerg Skov shows the previously mentioned differences in the sculpture.

Discussion: I refer with some hesitation the material to the genus Coptochetus, since a specimen with a complete labrum is missing. Further, the nucleus on the protoconch is not granulated like the nucleus on $C$. scalaroides, the type species of the genus. However, the sculpture with the dominating collabral ribs and the weaker spiral bands is in agreement with the sculpture of Coptochetus, and the aperture and the canal are in good agreement, too. The protoconch of the new species has some resemblance to the protoconch of the genus Parvisipho Cossmann, 1889 , but species belonging to this genus have a distinct spiral sculpture and weaker collabral sculpture.
Exilioidea elatior (Beyrich, 1848) has some resemblance to the new species in shape and axial sculpture, but the spiral sculpture, the convexity of the whorls, the protoconch, the aperture and the canal are different. Exilioidea elatior is rather common in the claypit at Nr. Vissing.

The genus Coptochetus is known from the Eocene deposits of the Basin of Paris, from Eocene deposits of Australia and from Oligocene deposits of South America (Cossmann 1901: 114). Further, Kollmann and Peel (1983: 74) mention and picture 2 species (one of which is dubious) from the Paleocene of Nûgssuaq, West Greenland. A dubious Coptochetus is "Fusus" strictus Briart et Cornet, 1870 from Calcaire de Mons, mentioned and pictured by Glibert (1973: 67 , pl. 11, fig. 20). This species has, according to Glibert, a protoconch similar to Coptochetus, but it lacks spiral sculpture.

Coptochetus (s.lat.) danicus n.sp. seems to be in good agreement with $C$. scalaroides with regards to sculpture, aperture and canal. The new species is characterised by the spiral sculpture of broad bands, which are strongest abapically on the whorls and almost invisible adapically. This sculpture separates $C$. danicus from all other, by me known species of the genus Coptochetus.

Acknowledgements. I am A. W. Janssen, Rijksmuseum van Geologie en Mineralogie, Leiden, greatly indebted for his direct comparison of a specimen of Cerithiopsis jutensis with the type material of $C$. vandermarki in the Museum of Natural History, Rotterdam and for his statement. I am very indebted to Dr. R. Janssen, Forschungsinstitut Senckenberg, Frankfurt, for his very friendly loan of 2 paratypes of Cerithiopsis soellingensis (SMF 251 400/2). Furthermore, W. Lappann, HeiligenhausIsenbügel, BRD, is thanked for his very friendly loan of material of Coptochetus scalaroides. Anne-Lise Mikkelsen, Geologisk Institut, Århus kindly improved the English manuscript. Finally, I am indebted to conservator Søren Bo Andersen, Geologisk Institut, Århus for making the photographical work, for practical help with the manuscript, and for placing material at my disposal.

\section{Dansk sammendrag}

To nye gastropoder, Cerithiopsis (Cerithiopsis) jutensis og Coptochetus (s.lat.) danicus fra Nordsøbakkenets $\emptyset$ vre Oligocan, opstilles. Slægten Cerithiopsis er i Nords $\emptyset$ bækkenets $\emptyset$ vre Oligocæn og Miocæn repræsenteret af adskillige arter, mens slægten Coptochetus ikke tidligere er anført fra dette område. De to nye arters affiniteter diskuteres. 


\section{References}

Cossmann, M. 1901: Essais de Paléconchologie comparée, Livraison IV. 293 pp, Paris.

Eriksen, K. 1937: En foreløbig Meddelelse om Tertiæret ved Brejning paa Sydsiden af Vejle Fjord. (Mit einer Zusammenfassung). Meddr. dansk geol. Foren. 9: 137-148.

Friis, H. \& Nielsen, O. B. 1979: International Correlation Programme Project 124, The NW European Tertiary Basin. Guide to Excursions, 4th and 5th of October, 1979. University of Aarhus: $55 \mathrm{pp}$.

Glibert, M. 1973: Revision des Gastropoda du Danien et du Montien de la Belgique. I. Les Gastropoda du Calcaire de Mons. Mém. Inst. Roy. Sci. Belg. 173. 116 pp.

Harder, P. 1913: De oligocæne Lag i Jærnbanegennemskæringen ved Aarhus Station. (Résumé en français). Danm. geol. Unders. (2) 22: $140 \mathrm{pp}$.
Janssen, A. W. 1967: Beiträge zur Kenntnis des Miocäns von Dingden und seiner Molluskenfauna 1. Geologica et Palaeontologica 1, 115-173, 8 figures, 14 plates.

Janssen, R. 1978: Die Mollusken des Oberoligocăns im Nordsee-Becken. 1. Scaphopoda, Archaeogastropoda, Mesogastropoda. Arch. Moll. 109 (1/3), 133-227, 1 figure, table 9-14.

Kollmann, H. A. and Peel, J. S. 1983: Paleocene gastropods from Nûgssuaq, West Greenland. Bull. Gronl. geol. Unders. 146: 115 pp.

Ravn, J. P. J. 1907: Molluskfaunaen i Jyllands Tertiæraflejringer. (Résumé en français). Kgl. Danske Vidensk. Selsk. Skr. 7. Rk. Afd. 3, 2; 215-386.

Sorgenfrei, T. 1958: Molluscan assemblages from the marine middle Miocene of South Jutland and their environments. Danm. geol. Unders. (2) 79:1-503. 